Jurnal Mahasiswa BK An-Nur : Berbeda, Bermakna, Mulia

Volume 7 Nomor 3 Tahun 2021

Tersedia Online: https://ojs.uniska-bjm.ac.id/index.php/AN-NUR

p-ISSN. 2460-9722 | e-ISSN. 2622-8297

\title{
DETERMINAN GANGGUAN PENDENGARAN PADA PEKERJA DI LINGKUNGAN BISING
}

\author{
Waspada $^{1}$, Handayani ${ }^{2}$ \\ ${ }^{1,2}$ Sekolah Pasca Sarjana Universitas Prof DR. Hamka, Fakultas Ilmu Kesehatan Masyarakat, \\ Jalan Warung Jati Barat, Jakarta Selatan, 12740, Indonesia, \\ E-mail: waspada1969@gmail.com/ +628128001194
}

\begin{abstract}
ABSTRAK
Permasalahan kebisingan merupakan isu keselamatan dan kesehatan kerja. Data global menunjukan 1,3 milyar penduduk dunia mengalami gangguan akibat bising. Tujuan dari penelitian ini adalah untuk mengidentifikasi determinan yang menjadi penyebab gangguan pada pekerja. Metode yang digunakan adalah studi literatur. Data yang digunakan dalam penelitian ini adalah data sekunder yang berasal dari artikel ilmiah nasional maupun internasional. Basis data yang digunakan yaitu Google Scholar, Mendeley, Science direct and Research Gate, Kriteria inklusi yang digunakan dalam penelitian ini yaitu jurnal yang diambil publish dalam 5 tahun terakhir dengan minimal Sinta 4 dan menggunakan jurnal Quartile 3 dan Quartile 4. Hasil penelitian didapatkan bahwa faktor usia, tingkat pendidikan, intensitas pajanan dan riwayat penyakit hipertensi dapat mempengaruhi kesehatan pendengaran para pekerja yang bekerja di lingkungan yang terpapar bising.
\end{abstract}

Kata Kunci : Kebisingan, Determinan, Gangguan Pendengaran

\begin{abstract}
Noise issues are occupational safety and health issues. Global data shows that 1.3 billion people worldwide are experiencing noise disruption. The purpose of the study was to identify determinants that cause disruption to workers. The method used is literature studies. The data used in this study is secondary data derived from national and international scientific articles. The database used is Google Scholar, Mendeley, Science direct and Research Gate, The inclusion criteria used in this study are journals taken published in the last 5 years with a minimum of Sinta 4 and using the journal Quartile 3 and Quartile 4. The results found that factors of age, education level, intensity of exposure and history of hypertension can affect the hearing health of workers who work in environments exposed to noise.
\end{abstract}

Keywords : Noise, Hearing Disorders Determinant

Dipublikasikan Oleh :

UPT Publikasi dan Pengelolaan Jurnal

Universitas Islam Kalimantan Muhammad Arsyad Al-Banjari Banjarmasin 


\section{PENDAHULUAN}

Global Burden Diseases menyebutkan bahwa 1,3 milyar penduduk dunia atau $16 \%$ orang dewasa mengalami gangguan pendengaran akibat bising (Armia Putri et al., 2021). Permasalahan kebisingan saat ini menjadi isu keselamatan dan kesehatan kerja. Kebisingan merupakan sumber bunyi yang tidak diinginkan dan berdampak kepada fisik serta fisiologis pada manusia (Balirante et al., 2020). Gangguan pendengaran akibat bising (Noise Included Hearing Loss) mengakibatkan penurunan fungsi pendengaran secara bertahap yang berdampak pada aspek kehidupan dan kesehatan manusia.

Hasil Riset Kesehatan Dasar (Riskesdas) tahun 2013 menunjukan bahwa masalah gangguan pendengaran menjadi permasalahan kesehatan di Indonesia. Untuk mengatasi permasalahan gangguan kesehatan, pemerintah melakukan upaya promotif dan preventif kepada masyarakat dengan berbagai pendekatan (Kemenkes RI, 2018)

Beberapa faktor seperti pengaruh usia, pendidikan pekerja, intensitas pajanan kebisingan, masa kerja serta riwayat penyakit hipertensi dapat mempengaruhi gangguan pendengaran pada pekerja di lingkungan bising. Berdasarkan faktor -faktor tersebut pentingnya upaya pencegahan yang dilakukan agar permasalahan gangguan akibat pendengaran pada pekerja dapat ditanggulangi dengan baik.

\section{METODE}

Penelitian ini menggunakan pendekatan Studi Literature Review yang bertujuan untuk mengetahui determinan yang mempengaruhi kesehatan pendengaran pekerja yang bekerja di lingkungan dengan resiko bising. Pengaruh usia, pendidikan pekerja, intensitas pajanan kebisingan, riwayat penyakit hipertensi dan masa kerja mempunyai pengaruh dalam menentukan kesehatan pendengaran pekerja di lingkungan bising. Data basis yang digunakan dalam penelitian ini Google Scholar, Mendeley, dan Science direct Research Gate. Strategi dalam kajian literatur menggunkan kata kunci kebisingan dan determinan bising pekerja.

\section{HASIL DAN PEMBAHASAN}

Berdasarkan hasil pencarian literatur di dapatkan beberapa artikel yang tersedia pada data base Google Scholar, Mendeley, Science direct Research Gate. Pencarian literatur dilakukan sesuai dengan kata kunci yang ditentukan. Namun, setelah dilakukan skrining lebih lanjut, diperoleh 5 literatur terpilih sesuai tabel berikut :

Tabel 1. Hasil Tinjauan Literatur

\begin{tabular}{|c|c|c|c|c|}
\hline No. & Judul Penelitian & Metode & Hasil & $\begin{array}{c}\text { Keterangan } \\
\text { Sumber }\end{array}$ \\
\hline 1 & $\begin{array}{l}\text { Occupational Noise and } \\
\text { Age : A Logitudinal } \\
\text { Study of Hearing } \\
\text { Sensitivity As A Funtion } \\
\text { of Noise Exposure and } \\
\text { Age in South African } \\
\text { Gold Mine Worker }\end{array}$ & $\begin{array}{l}\text { Studi } \\
\text { Logitudinal } \\
\text { dengan } \\
\text { menggunakan } \\
\text { analisi regresi } \\
\text { mixed effect }\end{array}$ & $\begin{array}{l}\text { Adanya } \\
\text { pengaruh yang } \\
\text { signifikan antara } \\
\text { usia dan paparan } \\
\text { kebisingan } \\
\text { terhadap } \\
\text { pendengaran } \\
\text { pekerja. }\end{array}$ & $\begin{array}{l}\text { South African } \\
\text { Journal Of } \\
\text { Communication } \\
\text { Disorders ISSN : } \\
2225-4765 \\
\text { (Grobler et al., } \\
2020 \text { ) }\end{array}$ \\
\hline 2 & $\begin{array}{l}\text { Pencegahan Noise } \\
\text { Induced Hearing Loss } \\
\text { Pada Pekerja Akibat } \\
\text { Kebisingan }\end{array}$ & $\begin{array}{l}\text { Literature } \\
\text { Review }\end{array}$ & $\begin{array}{l}\text { Adanya } \\
\text { perbedaan yang } \\
\text { signifikan antara } \\
\text { tinggkat } \\
\text { pendidikan } \\
\text { dengan } \\
\text { kepatuhan } \\
\text { penggunaan } \\
\text { Alat Pelindung }\end{array}$ & $\begin{array}{l}\text { Jurnal } \\
\text { Agromedicine } 4 \\
\text { (2) } \\
\text { (Mayasari \& } \\
\text { Khairunnisa, 2017) }\end{array}$ \\
\hline
\end{tabular}

Dipublikasikan Oleh :

UPT Publikasi dan Pengelolaan Jurnal

Universitas Islam Kalimantan Muhammad Arsyad Al-Banjari Banjarmasin 


\begin{tabular}{|c|c|c|c|c|}
\hline & & & Diri (APD) & \\
\hline 3 & $\begin{array}{l}\text { Hubungan Intensitas } \\
\text { Paparan Bising dan } \\
\text { Masa Kerja dengan } \\
\text { Gangguan Pendengaran } \\
\text { Pada Karyawan PT. X }\end{array}$ & $\begin{array}{l}\text { Desain cross } \\
\text { sectional }\end{array}$ & $\begin{array}{l}\text { Adanya } \\
\text { hubungan antara } \\
\text { intensitas } \\
\text { kebisingan dan } \\
\text { masa kerja } \\
\text { dengan } \\
\text { gangguan } \\
\text { pendengaran } \\
\text { pekerja PT. X }\end{array}$ & $\begin{array}{l}\text { Jurnal Kesehatan } \\
\text { Lingkungan } \\
\text { Indonesia } 15 \text { (1), } \\
2016,22-27 \\
\text { (Marisdayana et } \\
\text { al., 2016) }\end{array}$ \\
\hline 4 & $\begin{array}{l}\text { The Effect of Noise and } \\
\text { Work Period To } \\
\text { Hearing Threshold } \\
\text { Value in Textile Industry } \\
\text { Workers }\end{array}$ & $\begin{array}{l}\text { Observasional } \\
\text { analitik dengan } \\
\text { pendekatan } \\
\text { cross sectional }\end{array}$ & $\begin{array}{l}\text { Adanya } \\
\text { pengaruh masa } \\
\text { kerja terhadap } \\
\text { nilai ambang } \\
\text { pendengaran } \\
\text { pekerja }\end{array}$ & $\begin{array}{l}\text { Journal of } \\
\text { Industrial Hygiene } \\
\text { and Occupational } \\
\text { Health Vol } 2 \text { No } 2 \\
\text { (Sumardiyono et } \\
\text { al., 2018) }\end{array}$ \\
\hline 5 & $\begin{array}{l}\text { Hubungan Hipertensi } \\
\text { Dengan Gangguan } \\
\text { Pendengaran } \\
\text { Sensorineural Pada } \\
\text { Lanjut Usia }\end{array}$ & $\begin{array}{l}\text { Studi analisis } \\
\text { observasional } \\
\text { dengan desain } \\
\text { potong lintang }\end{array}$ & $\begin{array}{l}\text { Terdapat } \\
\text { hubungan } \\
\text { bermakna antara } \\
\text { hipertensi dang } \\
\text { gangguan } \\
\text { pendengaran } \\
\text { sensorineural }\end{array}$ & $\begin{array}{l}\text { Fakultas } \\
\text { Kedokteran } \\
\text { Universitas } \\
\text { Trisakti Jakarta, } \\
2019 \\
\text { (Ilham. 2020) }\end{array}$ \\
\hline
\end{tabular}

\section{Faktor Usia}

Usia mempegaruhi mekanisme ketahan tubuh dan kapasitas kerja bagi tenaga kerja. Semakin tua usia pekerja semakin besar tingkat kelelahan pada pendengaran dan butuh waktu yang lama mengembalikan keadaan normal (recovery) setelah terpapar aktivitas bising di lingkungan kerja. Paparan kebisingan yang terjadi secara bertahap dapat mempengaruhi kesehatan pendengaran pekerja yang berakibat hilangnya pendengaran akibat kebisingan. Hal ini merupakan penyebab secara langsung terhadap kerusakan pada sel-sel rambut di telinga dalam.

\section{Pendidikan Pekerja}

Dalam hierarki pengendalian risiko penggunaan APD merupakan tinggkatan terakhir yang dilakukan untuk melindungi pekerja dari bahaya akibat kerja. Seseorang yang bekerja di lingkungan bising berpotensi mengalami gangguan pendengaran. Untuk dapat meminimalisir risiko yang berdampak pada pendengaran penggunaan ear muff dan ear plung dapat menjadi solusi yang tepat, akan tetapi banyaknya pekerja yang tidak patuh dalam penggunaan APD dipengaruhi oleh beberapa faktor salah satunya tinggkat pendidikan. Pekerja yang memiliki tinggkat pendidikan yang tinggi memiliki pengetahuan dan kesadaran yang tinggi terhadap pentingnya penggunaan APD untuk keselamatan diri.

\section{Intensitas Pajanan}

Salah satu masalah utama kesehatan kerja adalah kebisingan. Dari beberapa literature menyebutkan proporsi pekerja yang bekerja selama $8 \mathrm{jam} / \mathrm{hari}$ dengan intensitas pajanan kebisingan $>85 \mathrm{~dB}$ (melebihi Nilai Ambang Batas) lebih banyak menderita gangguan pendengaran jika dibandingkan dengan pekerja yang bekerja dengan intensitas pajanan $<85 \mathrm{~dB}$ atau dibawah Nilai Ambang Batas (NAB).

\section{Masa Kerja}

Perhitungan masa kerja dimulai ketika pekerja mulai bekerja di sebuah perusahaan. Dari studi literature menyebutkan bahwa adanya hasil signifikan yang bermakna yang menunjukan hubungan antara Nilai Ambang Pendengaran (NAP) pekerja dengan masa kerja. Semakin lama pekerja bekerja semakin rendah nilai ambang pendengarannya.

\section{Dipublikasikan Oleh :}

UPT Publikasi dan Pengelolaan Jurnal

Universitas Islam Kalimantan Muhammad Arsyad Al-Banjari Banjarmasin 


\section{Riwayat Penyakit Hipertensi}

Hipertensi merupakan kondisi yang terjadi akibat tekanan darah terhadap dinding arteri. Penyakit ini mempunyai prevalensi yang cukup tinggi yang menimbulkan kerusakan terhadap organ target salah satunya kerusakan system pendengaran yang menjadi penyebab peninggkatan ambang pendengaran sehingga berdampak terhadap gangguan pendengaran.

\section{PENUTUP}

Lingkungan kerja yang bising merupakan salah satu penyebab terjadinya gangguan pendengaran pada pekerja. Beberapa faktor-faktor seperti usia pekerja, tinggkat pendidikan, intensitas pajanan, masa kerja serta riwayat penyakit... Mempunyai pengaruh terhadap kesehatan pendengaran pekerja. Untuk itu dengan adanya faktor determinan tersebut diharapkan dapat menjadi acuan di dalam pelaksanaan program keselamatan dan kesehatan kerja di lingkungan kerja setempat serta perlunya dilakukan pemeriksaan berkala kepada pekerja untuk mengetahui sejauh mana kerusakan yang terjadi dan tindakan pencegahan dapat dilakukan dengan cepat dan tepat.

\section{REFERENSI}

Armia Putri, B., Halim, R., \& Suryani Nasution, H. (2021). Studi Kualitatif Gangguan Pendengaran Akibat Bising / Noise Induced Hearing Loss (NIHL) Pada Marshaller Di Bandar Udara Sultan Thaha Kota Jambi Tahun 2020. Jurnal Kesmas Jambi. https://doi.org/10.22437/jkmj.v5i1.1240 0

Balirante, M., Lefrandt, L. I. R., \& Kumaat, M. (2020). Analisa Tingkat Kebisingan Lalu Lintas Di Jalan Raya Ditinjau Dari Tingkat Baku Mutu Kebisingan Yang Diizinkan. Jurnal Sipil Statik.

Grobler, L. M., Swanepoel, D. W., Strauss, S., Becker, P., \& Eloff, Z. (2020). Occupational noise and age: A longitudinal study of hearing sensitivity as a function of noise exposure and age in south african gold mine workers. South African Journal of Communication Disorders. https://doi.org/10.4102/sajcd.v67i2.687
Ilham, R. M. (2020). Hubungan hipertensi dengan gangguan pendengaran sensorineural pada lanjut usia. Skripsi2019.

Kemenkes RI. (2018). Telinga Sehat Investasi Masa Depan. Kementerian Kesehatan RI.

https://www.kemkes.go.id/article/view/ 18030500002/telinga-sehat-investasimasa-depan.html

Marisdayana, R., Suhartono, S., \& Nurjazuli, N. (2016). Hubungan Intensitas Paparan Bising Dan Masa Kerja Dengan Gangguan Pendengaran Pada Karyawan PT. X. JURNAL KESEHATAN LINGKUNGAN INDONESIA. https://doi.org/10.14710/jkli.15.1.22-27

Mayasari, D., \& Khairunnisa, R. (2017). Pencegahan Noise Induced Hearing Loss pada Pekerja Akibat Kebisingan Prevention of Noise Induced Hearing Loss on Workers Due to Noise Expossure. J Agromed Unila.

Sumardiyono, S., Hartono, H., Probandari, A., \& Setyono, P. (2018). THE EFFECT OF NOISE AND WORK PERIOD TO HEARING THRESHOLD VALUE IN TEXTILE INDUSTRY WORKERS. Journal of Industrial Hygiene and Occupational Health. https://doi.org/10.21111/jihoh.v2i2.188 3

Dipublikasikan Oleh :

UPT Publikasi dan Pengelolaan Jurnal

Universitas Islam Kalimantan Muhammad Arsyad Al-Banjari Banjarmasin 